Article

\title{
The Role of Political Collusion in Corporate Performance in the Korean Market
}

\author{
Daeheon Choi ${ }^{1}$, Chune Young Chung ${ }^{2, *}$, Soon-Ihl Samuel Hong ${ }^{2}$ and Jason Young ${ }^{3}$ \\ 1 College of Business Administration, Kookmin University, 77 Jeongneung-ro, Seongbuk-gu, \\ Seoul 02707, Korea; dhchoi@kookmin.ac.kr \\ 2 School of Business Administration, College of Business and Economics, Chung-Ang University, \\ 84 Heukseok-ro, Dongjak-gu, Seoul 06974, Korea; hongsoonil1@naver.com \\ 3 College of Business, Washington State University, Pullman, WA 99164, USA; bizfinace@naver.com \\ * Correspondence: bizfinance@cau.ac.kr
}

Received: 3 February 2020; Accepted: 5 March 2020; Published: 6 March 2020

\begin{abstract}
Many studies investigate collusion between political connections and firm performance, but Korean research on this topic is not very diverse. This study, based on financial data of listed Korean companies spanning the period from the 15th to the 19th Korean governments, analyzes whether political connections between governments and enterprises have a positive, negative, or no correlation with firm performance. The results show that the average return on assets for politically connected firms in the sample tends to be $10 \%$ higher than the corresponding value for sample firms that are not politically connected. Since existing studies measure political connections in a fragmented way, this study offers necessary implications for exploring the numerous structural problems of and solutions to the chronic issues currently faced by the Korean economy, as it investigates the economic policies from 1998 to 2018 and their influences on firm performance through the analysis of longer-term data.
\end{abstract}

Keywords: political connection; firm performance; economic policy

\section{Introduction}

For businesses, political connections imply that politics and the economy are closely related or that political and economic circles are deeply connected for their own benefits. This definition does not include concepts like "illegality" or "corruption". However, political connections are often indicated by illegal or corrupt transactions, which occur in many countries. James M. Buchanan, who received the Nobel Prize in Economics for public choice theory, a field of neo-liberalistic economics, argues that politicians and government officials are not spokesmen for the public good but rather businessmen who pursue personal interests. Public choice theory, therefore, stresses the importance of institutional devices that allow the economy to operate autonomously and remain separate from politics. However, when the basic principle of democratic politics is that laws and institutions are handled in the administrative arena, judicial and legislative affairs cannot be separated from the political process, and this theory fails to acknowledge the power of democracy and politics, which regulate and reorganize markets and economies to serve community interests. Under this theory, it is natural that neo-liberalistic prescriptions, such as deregulation, privatization, and public sector downsizing, which have negative effects, are negative solutions to the link between business and politics. Thus, examining the impacts of political connections on company performance is also natural. Regardless of their impacts, the political connections of major enterprises are deeply rooted in Korea. No administration has completely avoided the debate regarding the connection between politics and the economy. However, this phenomenon is observed not only in Korea but also in many other countries in economic transition, and it has attracted the attention of various researchers worldwide [1-4]. 
This interest has led to a wealth of empirical results, as studies find that political connectivity can boost corporate value with favorable regulatory conditions, import permits, financial bailouts, and government support to help some companies outmaneuver others [3,5-8]. These studies demonstrate the benefits of political links, but some define their profit sources by focusing on external factors, such as higher levels of corruption, weak institutional constraints, and inefficient legal protections, whereas others focus on internal factors, such as poor governance and low R\&D intensity. Studies also find negative effects of political connections, as politicians are not always merciful, and the abuse of political connections to elect politicians or achieve personal goals can adversely affect a company by, for example, weakening management practices, distorting incentives, misallocating investments, and raising rents. Eventually, the company's outcomes may be worse than ex-ante analyses suggest $[9,10]$. According to Faccio [6], long-term performance is often lower despite the significant benefits of political links owing to inefficient reductions in an entity's overall resources. Many interdisciplinary studies in the field of social science support this argument [11-14], given the conflicting empirical results concerning political links' relationship with entrepreneurship.

According to many studies and theories, political connections exist in the context of emerging and transitional economies. Shleifer and Vishny $[9,15]$ make the original argument that political capital enhances corporate value only when its benefits are greater than its marginal costs; thus, they describe political connections as a type of "game" between the general public, political actors, and economic actors, who are perpetually controlled by incomplete contracts. That is, reasonable economic actors can politically benefit from appointing politically relevant directors, as they offer knowledge and experience in government procedures [16], provide implicit and timely information regarding corporate policy [17], and can indirectly try to provide favors to organizations that are powerful enough to adjust economic policy in their favor [2]. Of course, the corresponding economic costs (e.g., lobbying, bribery, political campaigns, and various direct or indirect contributions) are taken into account in political networks with political actors [18]. Similarly, empirical evidence shows that Taiwan's companies with poor governance are likely to make political connections for corporate value owing to their high marginal profits and low marginal costs [19]. However, some findings suggest that the ties between political connections and entrepreneurship may not be captured or explained even within emerging and transitional economies.

First, Hillman, Zardkoohi, and Bierman [20] claim that many companies seek to link their political networks over the long term rather than for specific issues, distinguishing between "transactional approaches" and "relational approaches". Transactional approaches are defined as short-term contracts that can be more flexible and efficient in dealing with politicians when political regimes change frequently. Firms can adjust their political networks to correspond with the current regime. Given the relatively short time frames and the focus on specific issues, both parties can negotiate contract terms or even terminate the contract if particular requirements or objectives are not fulfilled. A decline in a political partner's ability to provide resources increases the chance that a firm can find an alternative partner who provides a better fit and good solutions to issues. Lobbying for a particular issue and one-time political donations are typical examples of this approach.

Relational approaches, in contrast, entail sustained relationships between political and economic actors over time through trust and fair dealing. Professional relations outweigh political objectives. Firms maintain politically connected board members across different regimes owing to the necessity of their professional expertise and political ideologies. A mutually beneficial relationship creates incentives for both sides to continue the relationship. This conjecture is consistent with Kroszner and Stratmann's [21] suggestion that firms provide repeated political donations to legislators to increase their acceptance of (opposition to) favorable (unfavorable) government policies and to support other favors in the future. However, firms' investments in the relational approach can be costlier when the long-run returns are less certain. For instance, Indonesian firms that had close, long-term relationships with the Soeharto regime experienced poor long-term performance following his departure and had significant difficulty establishing connections with the new regime [22]. 
In another study of the link between politics and entrepreneurship, Peng and Luo [23] emphasize that the overall goal of political connections is creating (producing) government policies, which also supports the arguments of previous studies if the continued survival of businesses and positive outcomes are attainable. Political actors' main objectives are re-election [24], political survival [25], and political continuity over the long term [26]. Leuz and Oberholzer-Gee [22] describe anecdotes explaining that Indonesian companies closely related to the regime received preferential funding support, but when their sponsors lost power, they faced sudden difficulties and, thus, performed poorly under the new regime. In the U.S., empirical evidence on the political connections of S\&P 500 companies in response to the 2000 presidential election indicates that firms that were well connected to the Democratic Party experienced decreasing corporate value [1,27]. In summary, each of these studies highlights that interconnections (exchanges) between political and economic actors [6], gift exchanges [28], and embeddedness, defined as the degree to which economic activity is constrained by non-economic institutions [29], not only exist but have grown more with regard to structural change and relationships over time [20].

Second, studies indicate that changes in political and economic conditions are not always contemporaneous [30-32] and that the degree of regime change and economic privatization or liberalization processes may differ in emerging and transitional economies $[5,7,33]$. In transitional economies, the extent of regime change and the process of economic privatization can be categorized in four ways [32]. Countries like the Czech Republic, Poland, and Hungary have experienced collapsing hierarchies, and privatization is relatively well-regulated. In contrast, Ukraine and Russia, which also underwent collapsing hierarchies, are poorly privatized. In Uzbekistan, Kazakhstan, and Kyrgyzstan, one-party hierarchies have continued to survive, but the old regimes of these countries have directed privatization with few barriers to asset appropriation. In contrast, some countries (e.g., China, Belarus, Vietnam, Turkmenistan, and Tajikistan) have maintained one-party hierarchies, but privatization has been delayed and restricted. Walder [32] believes that substantial cross-country heterogeneity in the pace of political and economic reform can create opportunities and regulatory constraints and may lead to markedly different actions and reactions to political and economic actors in transition.

Overall, many scholars suggest that the "contingency perspective" is a useful analytical tool because countries have changed their scopes, sequences, speeds, and stages of economic reform extensively over time $[18,21,29,34]$. From the contingency perspective, most relationships between two variables are influenced by other variables [35]. Thus, no common set of strategic choices is optimal for all organizations and situations [36], as the optimal strategy depends on a specific set of conditions, such as the environment, technology, knowledge, culture, the organizational structure, and size. Whether a strategy satisfies these conditions determines the contingencies [37-39]. Burt [18] shows that the value of social and political capital depends on the network, background, and performance by analyzing 170 managers, including one of the largest U.S. electronics companies and the senior executives of major U.S. financial institutions. Peng and Luo [23] demonstrate that managers' social bonds and contacts and the impacts of networks vary across Chinese enterprises with diverse ownership types/forms, business sectors, scales, and industrial growth rates. In a recent study, Zhu and Chung [17] use data from Taiwan's 250 largest business groups from 1998 to 2004 to find that the benefits of social links between politicians and companies entering the market depend on their external competitive environments and the internal resource profiles of each company. As Peng and Luo [23] mention, the contingent value of political capital provides a framework for specific predictions capturing political and economic actors' interactions and, thus, identifying the impact of political connections on entrepreneurship in emerging and transitional economies.

Conversely, although past studies have demonstrated that political links have either positive, negative, or no value to entrepreneurship in a given environment, few investigate whether environmental changes can lead to changes in companies' net values in emerging and transitional economies $[1,7,17,27]$. However, these studies have important limitations. Goldman, Rocholl, and So [1] find that companies linked to Republicans experienced positive changes in value, whereas those 
linked to Democrats experienced negative changes. However, determining whether these results represent the data or the overall business level is difficult, as they are based on the stock returns of S\&P 500 corporate board members in the U.S. during the Republican Party's victory in the 2000 presidential election. They focus only on the year 2000, which is a rather short period for analyzing different aspects of board members' political connections and dynamic changes in corporate value over time due to environmental factors. Moreover, Goldman, Rocholl, and So [27] focus on changes in the political situation before and after the 1994 mid-term election and the 2000 presidential election in the U.S.; however, they utilize a sample of boards of directors of S\&P 500 firms and the allocation of government procurement contracts, which unfortunately may not clearly indicate value at the enterprise level. Similarly, Claessens, Feijen, and Laeven [7] consider corporate campaign contributions before and after the 1998 and 2002 Brazil elections and find that greater contributions to federal government officials increase stock yields by providing smoother access to finance. However, the corporate value data have similar problems to those of Goldman, Rocholl, and So [27].

Zhu and Chung [17] observe 250 companies that are politically linked to major parties pushing for market entry during the first political transition from the original Kuomintang to the Democratic Progressive Party in 2000. China's Kuomintang (/'kwou,min'ta:n, -'tæy/, [10]), also spelled "Guomindang" and often alternatively translated as the Nationalist Party of China or the Chinese Nationalist Party, is a major political party in the Republic of China based in Taipei that was founded in 1911 and is an opposition political party in the Legislative Yuan. The Democratic Progressive Party is a Taiwanese nationalist and centrist political party. Controlling both the Taiwan presidency and the unicameral Legislative Yuan, it is the majority ruling party and the dominant party in the Pan-Green Coalition. Zhu and Chung [17] find that, during this transition, market access seems to fall for companies linked to rival parties. However, they also consider a relatively short survey period, and they use market access rather than the enterprise value as an indicator. Thus, the effect of changes in politics and the economic environment on corporate value over time remains unclear.

The positive or negative value of political capital can change if government policy changes, as the government plays a crucial role in setting the market size and scope. These policies can include levying taxes, providing subsidies, regulating environmental laws, regulating industrial policies, and controlling companies' market entrances and exits [40-43]. For example, Johnson and Mitton [44] show that politically friendly enterprises in Malaysia tended to lose corporate value in the first phase of the financial crisis from July 1997 to August 1998 but that political connections with Prime Minister Mahathir Mohamad were positively related to entrepreneurship in September 1998 owing to changes in government policies and sponsors. Similarly, Khwaja and Mian [3] identify political connections in Pakistan based on the Banking Law of 1974 and find that some businesses were given preferential treatment and others were damaged, allowing the Pakistani government to appoint senior banking executives to the government to determine credit and lending policies.

Above all, the positive or negative value of political capital can change during a regime change. Fisman [5] and Leuz and Oberholzer-Gee [22] find empirical evidence that companies with political ties to former Indonesian dictator Soeharto experienced significant economic gains that became sizable negative returns when Soeharto's health status became an issue. In contrast, Holburn and Vanden Bergh [45] and Zhu and Chung [17] focus on companies' political strategies for surviving potential negative discrimination or exclusion in hostile environments. Clearly, if a company has close connections to the previous political administration and their backers lose power to the opposition, the company could be the target of retaliation by the new regime for directly or indirectly altering the regulatory environment. This argument illustrates the mechanical characteristics of political connections by which positive (negative) political ties can become negative (positive) owing to exogenous factors.

Nevertheless, few empirical studies consider the dynamics between political connections and firm value in emerging and transitional economies. The most closely related studies are those of Do, Lee, Nguyen, and Nguyen [46] and Siegel [29]. The former use a regression discontinuity design 
to show that social network-based political connections provide positive and significant cumulative returns on firm value for the elections of 35 governors from 1999 to 2010 in the U.S. In statistics, econometrics, political science, epidemiology, and related disciplines, a regression discontinuity is a quasi-experimental pre-test/post-test design that elicits an intervention's causal effect by assigning a cut-off or threshold value above or below which the intervention is assigned. Comparing observations lying close to the threshold on either side allows the researcher to estimate the average treatment effect in environments in which randomization is unfeasible. Do, Lee, Nguyen, and Nguyen [46] apply this method to verify political connections based on a network of firm directors and politicians and demonstrate the opposite impacts on overall firm value for rival business groups as time passes. However, their study does not include the dynamic characteristics of the firm value or consider the possibility that political connections can cause negative regime change effects through punishment.

Siegel [29] conducts a similar study of 665 South Korean companies from 1987 to 2003 and finds that sociopolitical network ties to the current regime are positively correlated with the rate of cross-national strategic alliances but that connections to the opposition regime are negatively correlated with that rate. From a contingency perspective, Siegel [29] investigates how an unanticipated event in a political regime can abruptly change a political asset into a liability in the long term. However, he solely concentrates on cross-national strategic alliances rather than on firm value in evaluating political connections.

Thus, to understand changes in the value of political connections during periods of political turnover, we examine the effect of political connections between businesses and the government on the firm value in South Korea from 1998 to 2018. South Korea is appropriate for investigating dynamic changes in the firm value because it is a representative emerging economy owing to its drastic changes from 1960 to 1990 . Political ties played a very important role in this major transition. Furthermore, many of today's major enterprises have consistently received political support over time. In addition, we specifically analyze data on firms listed on the Korea Stock Exchange over five previous administrations, including the current government, to capture differences in firm value when the government's economic policies are comparatively favorable to major companies and when they are not. Thus, examining changes in the values of Korea's listed companies across regimes can help clarify whether these policies have positive or negative effects on firm value.

The composition of the remainder of this paper is as follows. Section 2 reviews the existing literature to discuss the positive and negative effects of political connections. Section 3 proposes specific hypotheses. Section 4 describes the sample and variables and discusses the analysis and results, and Section 5 presents conclusions.

\section{Literature Review}

As political connections are observed in developing countries and countries at the center of economic change, research continues to investigate whether their effects are positive or negative. Previous empirical evidence indicates that the interface between business and political connections is based mostly on corporate governance, and, thus, the relational approach highlights the importance of network activity to improve overall corporate performance. However, the empirical results in these environments are somewhat mixed. Some studies find that political connections positively affect firm performance $[1,5,47]$ and note that these effects yield benefits associated with the government, such as banking loans, tax benefits, and market dominance [7,44,48]. Additionally, these benefits tend to be even stronger under interventionist governments or weak protections for private property rights [6].

Moreover, Agrawal and Knoeber [16] show that politically involved outside directors on corporate boards are important based on a sample of Forbes 800 companies between 1987 and 1990 in the U.S. These directors can prevent agency problems, offer crucial information about government procedures, help establish political corporate strategy, and improve overall firm performance. Another study uses data on China's listed state-owned enterprises (SOEs) from 2001 to 2005 to find that poorly performing companies noticeably tend to appoint politically experienced head executives from the 
government as the chairman or CEO to serve as a disciplinarian or supervisor and increase the overall firm performance [49].

Other studies, however, present different results, showing that political connections negatively impact firm performance. Chang and Wong [50] report that, in China, political connections often negatively affect corporate decision-making and, thus, are more likely to harm general firm performance. Chen, Fan, and Wong [51] empirically show that China's politically experienced CEOs and directors negatively influence the three-year post-IPO stock returns of 617 A-share listed firms on the Shanghai and Shenzhen Stock Exchanges from 1993 to 2000. Using a sample of 245 private companies based in 41 different countries, Boubakri, Cosset, and Saffar [14] show that the accounting results of politically supported firms are worse than those of firms lacking support. In addition, Faccio [6] finds that politically connected companies perform comparatively poorly in 42 countries. Fan, Wong, and Zhang [13] find the same pattern among China's listed companies with politically connected CEOs.

Correspondingly, Liu, Luo, and $\mathrm{Xu}$ [52] use a sample of A-share listed Chinese firms between 1994 and 2010 to show that politically connected firms are more likely to overinvest in political connections, but these overinvestments mostly negatively affect firm performance. As Hellman and Schankerman [53] confirm, the relationship between the government and firms is mainly heterogeneous with regard to the quality and structure of corporate governance, the extent of government intervention, and the level of economic reform; the specific combination of elements can greatly increase or decrease firm value. Shen, Wang, and Lin [54] use data on 71,069 individual bank loan contracts of Taiwan's listed firms between 1997 and 2009 to verify that companies with continued corporate governance less strongly prefer to pursue political connections. In contrast, firms with weak corporate governance more strongly prefer political connections. Thus, corporate governance and political connections are substitutes to a degree.

Other studies focus more on corruption. For example, Khwaja and Mian [3] use loan-level information from 1996 to 2002 to report that more than 90,000 political firms in Pakistan have more access to government bank loans through relationships between politicians and their board members. Additionally, political-business collusion is identified in the Hong Kong Stock Exchange between 2003 and 2008 based on the return on equity (ROE) and market-to book ratios of listed companies whose corporate boards include members of the election committee, who increase the firm value [55]. Additionally, previous studies examine the relationship between transparency and firm value and demonstrate that the relationships between political (i.e., former or incumbent ministers and senior government officials) and economic actors (i.e., chairmen or CEOs) do not significantly improve the firm value when corruption is low [56]. However, in the context of post-IPO companies in Singapore from 1998 to 2006, political connections offer positive benefits to entrepreneurship in industries that are strictly regulated and controlled by the government. Similarly, between 2006 and 2007, Niessen and Ruenzi [57] find a tendency to place some firms' political networks far ahead of those of companies that were not connected to the Bundestag elected after the new Transparency Act was introduced in Germany. Hellman, Jones, and Kaufmann [11] introduce the theoretical concept of a "capture economy," associated with corruption within transition economies, in which "public officials and politicians privately sell underprovided public goods and a range of rent-generating advantages to individual firms." They additionally contrast state capture (i.e., "firms shaping and affecting formulation of the rules of the game through private payments to public officials and politicians") with influence (i.e., doing the same without using payments) and administrative corruption (i.e., "petty forms of bribery in connection with the implementation of laws, rules, and regulations"), and they verify that political connections to public officials and politicians can improve firm performance except in the case of "administrative corruption".

Moreover, many authors explicitly document examples of changes in connectivity or behavior among political and economic actors to adapt to changes in China's political and economic environments. Haveman et al. [58] analyze data from all listed companies from 1992 to 2007 and find that the links between state officials and the CEOs or top executives of businesses improve overall firm performance 
through preferential access to estimated bank loans. In addition, they use panel data spanning from 1998 to 2007 and taken from 86,827 manufacturing companies, 350 politicians, and companies motivated directly or indirectly by the Central Committee of the Communist Party of China and the State Council to demonstrate a gradual positive impact on firm performance [59]. Nee and Opper [60] find that the effects of political connections are positively correlated with corporate competitive advantage before 2002, but a large national survey conducted by the World Bank in 2003 based on data from 2400 companies in 18 Chinese municipalities shows that economic transactions do not lead to these benefits under competitive market conditions. Scholars who specifically distinguish between business and political capital show that corporate network capital affects firm performance more positively than political network capital, which depends on institutions and market environments [61].

State socialism refers to any socialist political or economic perspective advocating for state ownership of the means of production either as a temporary measure in the transition from capitalism to socialism or as a characteristic of socialism. State socialism differs from libertarian socialism, which rejects the view that socialism can be constructed using existing state institutions or government policies. Overall, China's shift from state socialism to market-oriented capitalism implies that political and economic actors must evolve their thinking, behavior, and strategy to earn more profits as markets develop. As market competition gradually replaces the state in the allocation and redistribution of resources, political actors' power continues to decrease, but, according to Haveman et al. [58], these actors can effectively develop new sources of power, such as market entry/exit regulations, subsidies, taxes and capital, control licenses, and policymaking. As a result, political capital still retains its value relative to the new generation of "contingent" aspects for both political and economic actors as the market develops.

Additionally, several studies focus on crony capitalism, defined as "capital controls (that) enable politicians to support the financing of particular firms" [44]. It can also be described as "dominant political leaders us(ing) their power to the advantage of their families and friends, who benefit from government-created rents" [6]. According to Choi and Thum [28], the main aspect of crony capitalism is a mutual "gift exchange" between governments and politically related companies. Other scholars describe crony capitalism as the "interdependence" between political and economic actors [62]. Alternatively, political actors can provide specific companies with special support by reducing regulatory requirements, awarding government contracts, or providing financial relief when economic actors' ultimate goal is improving firm performance. In contrast, economic actors can continue to support certain political actors through campaign contributions, donations, or other activities when a political actor's ultimate goal is winning an election. However, the cross-country empirical evidence is mixed. During five U.S. elections between 1983 and 1992, companies entered contracts that contributed to achieving the goals of legislators (i.e., senators and members of Congress) while ensuring that they could establish Political Action Committees, which encourage repeated interactions, reputation building, and long-term relationships [24]. In Italy, politically connected companies are more likely to receive lower interest rates from state-owned banks than from private banks, which exercise great control over the results of the party's elections [63]. Interestingly, a study of 789 companies listed on the Berlin Stock Exchange from April 1932 to May 1933 demonstrates the positive impact of the political connections between the German industry and the Nazi Party on stock returns [64]. Evidence from the 2000 largest companies in Taiwan shows that business leaders who seek public office produce better value for their own firms than for other companies [36]. Another study using data from Taiwanese firms listed on the Taipei Political Exchange during the 2008 presidential election shows that their price-to-earnings ratios are highly positive with respect to unresolved issues between Taiwan and the People's Republic of China [65]. Furthermore, in Brazil, the political network between businesses and politicians is found to directly benefit from business through mutual contributions to the elections of presidents, governors, senators, and federal and state congressmen using data from multistage listed companies from 2003 to 2006 [66]. Some studies find the opposite results. In France, politically related CEOs negatively impact firm performance for publicly 
traded companies from 1987 to 2002 [12]. A study using data sets from SOEs listed overseas and on China's domestic stock exchange finds that stronger political connections are statistically significantly negatively associated with firm performance [67]. Surprisingly, anecdotal evidence from 2001 called the "Jeffords effect", which means that changes in the political landscape greatly affect firms' market values, indicates that politically connected companies had fairly positive or negative changes in market value during unexpected political landscape changes impacting the Republican and Democratic parties in the U.S. [68].

Finally, some scholars investigate the overall value of predicted political capital and firm performance worldwide based on meta-analyses and systematic reviews. A meta-analysis combines the results of multiple scientific studies and can be performed when multiple scientific studies address the same question, with each individual study reporting measurements that are expected to have some degree of error, and a systematic review is a literature review that uses systematic methods to collect secondary data, critically appraise research studies, and synthesize the findings qualitatively or quantitatively. Boubakri, Cosset, and Saffar [14] identify a positive correlation between political connections and firm value through a unique data set of 234 politically connected companies in 12 developed and 11 developing countries as an international event study over the previous three years. A systematic review confirms via 56 methodologies that an enterprise's political activities strongly improve firm performance in a country's overall institutional context [69]. Moreover, Stam, Arzlanian, and Elfring [70] use 59 meta-analytical methods to find a positive and significant relationship between entrepreneurs' networks and small businesses' performance. However, although the 19,884 companies and 17,033 politicians from 42 countries in the sample enjoy significant benefits, such as debt financing, tax cuts, and increased market power, poor firm performance due to politicians' track-and-field activities can also occur [6]. In conclusion, the net value of political capital depends on a combination of factors in the political and economic environments that affect political and economic actors. Most studies show that these political connections are dominated by such factors as the degree of corruption, the intensity of institutional constraints, legal protections and judicial independence, government intervention and corporate governance, and the enterprise's characteristics (e.g., R\&D intensity, firm size, or leverage).

\section{Hypothesis Development}

The data on which this study was based include South Korea's last five governments. For the current government, data are only available for 2017 and 2018. The Park Chung-hee administration was the most representative administration that provided opportunities for large company growth, and many of Korea's conglomerates would not have achieved their current corporate growth without this administration's help in their early stages. Thus, this study is carried out based on the economic policies of each administration and the subsequent evaluations of these policies. Specifically, the administrations are divided into those that achieved friendly policies toward large businesses and contributed to business activities and those that did not. Specifically, the Kim Dae-jung government, the Roh Moo-hyun government, and part of the current regime are included in the latter group, as they mainly implemented policies supporting small and medium-sized enterprises (SMEs) rather than large companies, and the Park Geun-hye and Lee Myung-bak administrations are included in the former group, as they primarily carried out policies supporting large firms rather than SMEs.

Examining the economic policies of the last five Korean governments leaves no doubt that the amount of budget support for each sector differed and that the influence on business activities depended on the government's aims. Unlike the economic policies or commitments during these governments' campaigns, which were intended to be implemented early in each regime, the evaluations at the end of these regimes or later differ depending on the regimes' propensities. Whether these regimes had positive or negative impacts is difficult to determine by analyzing their policies. In conclusion, the indicators of firm performance and firm value for listed companies in Korea indicate whether previous regimes benefited or harmed the activities of large corporations, which are the backbone of 
Korea's economic growth. The following hypothesis is presented for evaluation using data from listed companies in Korea.

Hypothesis 1 (H1) The performance of large corporations may have improved during regimes that set policies in favor of large corporations.

\section{Data and Methodology}

\subsection{Sample}

This study focused on Korean firms listed on the Korea Stock Exchange from 1998 to 2018. Among the top 100 firms, we excluded 46 companies for which data were lacking in certain periods. Thus, of the top 100 companies across all industries, 54 companies with the highest market capitalization in the period were selected. However, we excluded firms in the financial and utility industries, as such firms were highly regulated. The data used for the empirical analysis were extracted from FnGuide Pro in Korea.

\subsection{Variables}

This study analyzed the impact of political connections on firm performance and firm value in Korea. We must consider the definition of political connections before explaining the variables. Many previous studies suggest definitions of political connections. According to Faccio [6], political connections occur when "one of the company's large shareholders or top directors, such as CEO, president, vice-president or secretary, is a member of the parliament, a minister, or the Chief of the State". Similarly, Boubakri, Cosset, and Saffar [14] define political connections as "at least one member of its board of directors or its supervisory board is or was a politician such as a member of parliament, a minister or any other top appointed-bureaucrat". According to Niessen and Ruenzi [57], in Germany, political connections are defined as "at least one member or delegate of the Bundestag, supervisory board or advisory council". Lastly, Haveman et al. [58] define political connections as "equal to one in years when the focal firm's CEO, at least one other top manager, or at least one member of the board of directors had served as the chief officer or deputy chief officer at the county level or above".

Considering the common definitions across studies, this study defines a firm as politically connected if one of the following criteria is met: (1) a CEO, chairperson, director, large shareholder, or top officer is or was a member of parliament, minister, top government official, or senior civil servant; (2) the CEO or chairperson of the firm publicly supports a presidential candidate or the firm's employees participate in the presidential campaign; (3) the CEO or chairperson is reported by at least one of the major newspapers to be supporting a certain political party; or (4) other social relations, such as ties within the Korean social network yonjul, kin ties, or school relations, exist. Hence, political support according to Criterion (4) varies across the sample firms, but it may not vary much over time because the executives of the sample firms may or may not have social relationships that function as political connections. Similarly, Criteria (1)-(3) vary across firms but may not change much over time because executives stay in the same positions for some time. This definition of political support is very close to that of Faccio [6], but it specifically adds a fourth yardstick reflecting Korea's sociopolitical environment. Like many other countries, South Korea has developed close relationships between politics and business. Furthermore, it is no exaggeration that many current Korean corporations gained numerous advantages for growth through political connections in their initial stages. Given this historical background, this study defines political connections as the periods in which the economic policies of the government in power are assessed to have been more favorable for large companies than for SMEs. This favorability is likely to have been directly related to the ruling party or the reasons for supporting it, as shown by Criteria (1), (2), and (3). In addition, the reason behind such favorable policies for major enterprises is likely the existing network with the government in power, as shown 
by Criterion (4). Thus, the definition of political connections used in this study is quite similar to the concepts described in the previous sections.

For example, in Korea, President Park Chung-hee allocated industrial rationalization funds to the shipbuilding industry and heavy industry projects on September 20, 1972, when KRW 3.72 billion were paid to Hyundai, which sought to build the shipyard, and KRW 3 billion were allocated to the petrochemicals industry. Thus, large industrial companies benefited greatly from the release of these large-scale policy funds.

To measure political connections, we first extract company financial statements from 1998 to 2018 from the FnGuide Pro database, and we then set a dummy variable for political support (PS) equal to one if a sample firm is associated with one of the four criteria described above and zero otherwise.

The dependent variables used to measure firms' economic performance in each year were the ROE and the return on assets (ROA), which are frequently used in previous studies. The ROA is generally defined as net income divided by total assets, and the ROE is defined as the net income divided by equity.

Additionally, we included most of the control variables used in recent prior studies of entrepreneurship in domestic and international contexts [71,72].

Initially, firm size (SIZE) may be closely related to performance. Kim [73] believes that firm size and firm value may be correlated owing to economies of scale. Demsetz and Lehn [74], however, argue that large firms have relatively low stakes in managers, which increases agency costs and, in turn, reduces corporate value. Thus, firm size is included as a control variable, and the natural logarithm of total assets is used to reflect size.

An increase in a company's debt ratio (LEV) may result in an increase in firm value owing to corporate tax savings, but an excessive debt ratio may also increase bankruptcy costs [75]. Myers [76] suggests that an excessively high debt ratio may increase the cost of agency problems for shareholders, whereas Jensen [77] and Stulz [78] suggest that an appropriate debt ratio may lower this cost owing to the additional free cash flows. We measured the debt ratio as the sum of short-term and long-term debt divided by the sum of total debt and equity.

Free cash flows (FCF) were also included as a control variable because the managers of companies with more free cash flows are more likely to pursue their own private interests, which may impair firm performance and value [77,79]. FCF is defined as cash flows from operating activity divided by total assets. The term "free cash flows" actually refers to net cash flows and is the net amount of cash available to investors. However, we used the term "free cash flows" rather than "net cash flows," as it is a commonly used term in finance studies. Hence, "free cash flows" and "net cash flows" can be used interchangeably.

Profitability is measured by dividing operating profits by the total sales [80]. Greater intangible assets, such as research and development (RD), may be strongly related to a firm's growth and shortand long-term performance, and advertising costs (ADV) may also affect the long-term firm value and performance [71]. Current related expenditures may increase a firm's market value by creating additional future cash flows. Both $R \& D$ and advertising costs are divided by total sales and used as control variables in the research model. Firm performance and value may be sensitive to the extent of competition in the commodity market, which can be reflected by sales and management costs (SGA), as they are used to maintain overall control of goods, products, and services. Sales and management costs are divided by total sales.

The definitions of the major variables are summarized in Table 1. 
Table 1. Variable definitions.

\begin{tabular}{cc}
\hline Variable & Definition \\
\hline ROE & Return on equity (net profits/total equity) \\
\hline ROA & Return on assets (net profits/total assets) \\
\hline PS & Dummy variable for political support (pro: 1/against: 0) \\
\hline LEV & Leverage (total liabilities/total assets) \\
\hline SIZE & Firm size (log of total assets) \\
\hline RD & $\begin{array}{c}\text { Research and development costs } \\
\text { (R\&D expenses/total sales) }\end{array}$ \\
\hline FCF & $\begin{array}{c}\text { Free cash flows } \\
\text { ADV }\end{array}$ \\
\hline SGA & $\begin{array}{c}\text { Advertising expenses } \\
\text { (cadvertising expenses/total sales) }\end{array}$ \\
\hline
\end{tabular}

\subsection{Estimated Model}

Based on these key variables, the following research models were used in the empirical analysis.

$$
\begin{aligned}
& \mathrm{ROA}_{i t}=\beta_{0}+\beta_{1} \mathrm{PS}_{\mathrm{it}}+\beta_{2} \mathrm{SIZE}_{\mathrm{it}}+\beta_{3} \mathrm{LEV}_{\mathrm{it}}+\beta_{4} \mathrm{RD}_{\mathrm{it}}+\beta_{5} \mathrm{FCF}_{\mathrm{it}}+\beta_{6} \mathrm{ADV}_{\mathrm{it}}+\beta_{7} \mathrm{SGA}_{\mathrm{it}}+\varepsilon_{\mathrm{it}} \\
& \mathrm{ROE}_{i \mathrm{t}}=\beta_{0}+\beta_{1} \mathrm{PS}_{\text {it }}+\beta_{2} \mathrm{SIZE}_{i \mathrm{t}}+\beta_{3} \mathrm{LEV}_{\text {it }}+\beta_{4} \mathrm{RD}_{\mathrm{it}}+\beta_{5} \mathrm{FCF}_{\text {it }}+\beta_{6} \mathrm{ADV}_{\text {it }}+\beta_{7} \mathrm{SGA}_{\text {it }}+\varepsilon_{i t}
\end{aligned}
$$

In estimating these regressions, we used a firm fixed effect model to reduce possible endogeneity that may arise from unobserved firm characteristics, where the variables are as defined above and $\varepsilon_{i t}$ is the error term. This model is based on those of Nee and Opper [60] and Ang, Ding, and Thong [56]. However, they focus on the effects of market structure and corporate governance on firm value, whereas we focused on the impacts of political regime changes and economic policies on firm value over time.

We associated all the variables for the 54 companies with dummy variables for the five political regimes. The first regime in this study (1998-2002) includes Kim Dae-jung's government. The second regime (2003-2007) covers Roh Moo-hyun's government. Lee Myung-bak's government is the third regime (2008-2012), and Park Geun-hye's government is the fourth regime (2013-2016). Finally, the fifth regime (2017-2018) covers the first two years of Moon Jae-in's current government.

\subsection{Summary Statistics}

Table 2 presents summary statistics for the 54 of the top 100 listed companies in Korea that have complete data from 1998 to 2018. We provided descriptive statistics for the number of observations and the mean, standard deviation, minimum, and maximum values of the main variables. The mean value of the ROA was 0.051 , and the mean value of the ROE was 0.105 . Hence, the average profitability of these companies was 10.4 percent based on the ROE and 5.1 percent based on the ROA. Moreover, the independent dummy variable PS equaled one, reflecting that a company met the definition of being politically connected, with frequency 0.479 and equaled zero with frequency 0.571 . The skewness of the variables was between -0.5 and 0.5 , which implies that the variables were fairly symmetrical. Additionally, the kurtosis for the variables was around three, suggesting that they largely followed a normal distribution and did not necessarily include outliers. Moreover, the average variance inflation factor (VIF) was less than six. Given the general rule of thumb for the VIF test, the variables were not substantially influenced by multicollinearity or autocorrelation. Thus, the key variables used in our empirical analyses behaved well with respect to the fundamental assumptions for ordinary least squares estimation, multicollinearity according to VIF tests, and their own skewness and kurtosis. 
Table 2. Summary statistics.

\begin{tabular}{|c|c|c|c|c|c|c|c|c|}
\hline Variables & Obs. & Mean & Std. Dev. & Min & $\operatorname{Max}$ & Average VIF & Skewness & Kurtosis \\
\hline ROE & 1134 & 0.105 & 0.254 & -2.390 & 4.168 & 3.321 & 0.343 & 3.124 \\
\hline $\mathrm{ROA}$ & 1134 & 0.051 & 0.069 & -0.575 & 0.850 & 4.343 & 0.234 & 3.312 \\
\hline SIZE & 1134 & 22.298 & 1.632 & 14.084 & 26.550 & 1.232 & 0.432 & 2.734 \\
\hline LEV & 1134 & 0.518 & 0.185 & 0.003 & 1.419 & 4.312 & 0.124 & 2.983 \\
\hline $\mathrm{RD}$ & 1134 & 0.011 & 0.024 & 0 & 0.384 & 5.643 & 0.317 & 2.412 \\
\hline FCF & 1134 & 0.094 & 0.085 & -0.218 & 0.521 & 4.342 & 0.115 & 3.331 \\
\hline ADV & 1134 & 0.015 & 0.029 & 0 & 0.373 & 5.333 & 0.024 & 2.984 \\
\hline SGA & 1134 & 0.216 & 0.229 & 0 & 1.018 & 1.535 & 0.512 & 2.877 \\
\hline \multicolumn{9}{|c|}{ Summary statistics for the binary variable } \\
\hline Variable & \multicolumn{2}{|r|}{ Value } & \multicolumn{3}{|c|}{ Frequency } & & & \\
\hline PS & \multicolumn{2}{|r|}{$\begin{array}{l}0 \\
1\end{array}$} & \multicolumn{3}{|c|}{$\begin{array}{l}0.571 \\
0.479\end{array}$} & & & \\
\hline
\end{tabular}

Table 3 presents the correlations between variables. The results of this analysis indicate statistically significant relationships between some variables, so we investigated the VIFs owing to concerns about multicollinearity among the variables. The analysis indicates that all variables should be included in the regression equation, as the largest value was not greater than ten and fell within the universal multicollinearity criterion [81].

Table 3. Correlation matrix.

\begin{tabular}{ccccccccc}
\hline & ROE & ROA & SIZE & LEV & RD & FCF & ADV & SGA \\
\hline ROE & 1 & & & & & & \\
ROA & $0.265^{*}$ & 1 & & & & & \\
SIZE & $-0.067^{*}$ & $-0.154^{*}$ & 1 & & & & \\
LEV & -0.012 & $-0.501^{*}$ & $0.181^{*}$ & 1 & & & \\
RD & -0.016 & $0.091^{*}$ & 0.029 & $-0.275^{*}$ & 1 & & \\
FCF & $0.143^{*}$ & $0.470^{*}$ & $-0.121^{*}$ & $-0.295^{*}$ & $0.176^{*}$ & 1 & \\
ADV & 0.054 & $0.196^{*}$ & $-0.228^{*}$ & $-0.245^{*}$ & $0.052^{*}$ & $0.111^{*}$ & 1 & \\
SGA & 0.044 & $0.123^{*}$ & $-0.204^{*}$ & $-0.207^{*}$ & $0.155^{*}$ & $0.152^{*}$ & $0.431^{*}$ & 1 \\
\hline \multicolumn{7}{c}{ Denotes significance at the $10 \%$ level. } \\
\end{tabular}

\subsection{Results}

Since the dependent variable is a continuous performance variable, multiple regression results are presented in Table 4. Analyzing the effects of Model 1, the results when the dependent variable was ROA indicate that the control variables SIZE, LEV, EBIT, RD, FCF, ADV, and SGA and the independent variable PS had significant effects. The average VIF of the key variables in the analyses was around seven, meaning that the variables were reasonably free from multicollinearity. In particular, the coefficients of PS in the two models were 0.005 and 0.005 , which were statistically significant at the $10 \%$ level or better. This result implies that politically connected firms' ROAs tended to be 0.005 higher than those of non-connected firms. Given that the average ROA of the sample firms was 0.051 , this difference reflected a $10 \%$ increase in the ROA. Thus, political connections significantly impacted large companies' performance based on the ROA.

Table 5 shows the results of the regression analyses of Models 1 and 2 including fixed effects. The test result (Hausman statistic of 7.89) shows that our model did not support the random effects model, and, thus, we adopted the fixed effects model to control for firm fixed effects. As with the multiple regression analysis results shown in Table 4, we found that all variables except for RD and 
SGA had statistically significant effects in Model 1 and that firm size and leverage had statistically significant negative effects. The coefficients of PS for both models in Table 5 were also positively and statistically significant, consistent with the findings in Table 4. Overall, the results of our empirical analyses were robust and suggest that political connections, as defined in this study, positively impact firm performance. One could argue that the regression of ROA on FCF was mis-specified because they are both performance measures. Hence, as a robustness check, we re-estimated Table 5 excluding FCF and found that our main result (the positive relationship between PS and ROA) did not change. Although they were not reported for the sake of brevity, the results are available upon request.

Table 4. Multiple regression results.

\begin{tabular}{ccc}
\hline & Model (1) & Model (2) \\
\hline \multirow{2}{*}{ PS } & $0.005^{* *}$ & $0.005^{*}$ \\
& $(0.014)$ & $(0.078)$ \\
SIZE & -0.002 & $-0.004^{*}$ \\
& $(0.157)$ & $(0.087)$ \\
LEV & $-0.146^{* * *}$ & $-0.184^{* * *}$ \\
& $(0.000)$ & $(0.000)$ \\
RD & -0.230 & -0.129 \\
& $(0.124)$ & $(0.200)$ \\
FCF & $0.295^{* * *}$ & $0.315^{* * *}$ \\
& $(0.000)$ & $(0.000)$ \\
ADV & $0.174^{* * *}$ & $0.438^{* * *}$ \\
& $(0.005)$ & $(0.000)$ \\
SGA & -0.012 & -0.006 \\
& $(0.109)$ & $(0.706)$ \\
Constant & $0.134^{* * *}$ & 0.192 \\
& $(0.000)$ & $(0.000)$ \\
\hline
\end{tabular}

Legend: * $p<0.05 ;{ }^{* *} p<0.01 ;{ }^{* * *} p<0.001$.

Table 5. Fixed effect regression results.

\begin{tabular}{|c|c|c|}
\hline & Model (1) & Model (2) \\
\hline \multirow{2}{*}{ PS } & $0.009^{* *}$ & $0.029^{*}$ \\
\hline & $(0.002)$ & $(0.087)$ \\
\hline \multirow{2}{*}{ SIZE } & $-0.007^{* * *}$ & -0.015 \\
\hline & $(0.000)$ & $(0.150)$ \\
\hline \multirow{2}{*}{ LEV } & $-0.125^{* * *}$ & $-0.271^{* * *}$ \\
\hline & $(0.000)$ & $(0.000)$ \\
\hline \multirow{2}{*}{ RD } & 0.079 & 0.508 \\
\hline & $(0.343)$ & $(0.291)$ \\
\hline \multirow{2}{*}{ FCF } & $0.097^{* * *}$ & 0.107 \\
\hline & $(0.000)$ & $(0.375)$ \\
\hline \multirow{2}{*}{ ADV } & $0.446^{* * *}$ & 0.705 \\
\hline & $(0.000)$ & $(0.112)$ \\
\hline \multirow{2}{*}{ SGA } & 0.009 & 0.080 \\
\hline & $(0.472)$ & $(0.272)$ \\
\hline \multirow{2}{*}{ Constant } & $0.199 * * *$ & 0.146 \\
\hline & $(0.000)$ & $(0.525)$ \\
\hline Firm fixed effects & YES & YES \\
\hline Year fixed effects & YES & YES \\
\hline
\end{tabular}

\section{Discussion}

The empirical relationship between political connections and firm value in emerging and transitional economies is still unclear, as explained in the literature review. Hence, to better understand the role of political connections during times of political turnover, this study investigated the effect of 
political connections between businesses and the government on the firm value in South Korea, where political ties have played a very important role in its major economic transition. In particular, we analyzed extensive data on the Korea Stock Exchange over five administrations, including the current government, to capture differences in the firm value when the government's economic policies are comparatively favorable to major companies and when they are not. Consequently, changes in the values of Korea's listed companies across regimes provide a unique empirical setting for examining whether these policies positively or negatively affect firm value. We utilized dummy variables to identify the impact of economic policy on firm performance owing to data availability. However, utilizing company-specific policies may be a better way to capture the policy impact. For example, Criscuolo et al. [82] provide a good example of an analysis using firm-specific policies. Nevertheless, our empirical analysis reveals that politically connected firms' ROAs tend to be $10 \%$ higher than the average ROA among sample firms that are not politically connected.

Previous studies simply consider that political network relationships provide either positive, negative, or no value to firms in the political and economic environment, but no conclusive empirical study investigates whether environmental changes can strongly lead to changes in companies' net values over time in emerging and transitional economies. Fundamentally, this study found that political network connections to the regime in power provide fairly positive benefits. Indeed, the relationship between economic policy and big businesses has become very important to entrepreneurship during administration changes after Korea's political and economic liberalization. Many previous studies focus on whether connections between political and economic actors affect entrepreneurship positively or negatively within emerging and transitional economies or whether the two are correlated $[3,5-7,11,13]$. This study, however, focused on firm performance based on whether historically assessed regimes set favorable policies toward big business, and we found positive results. Political connections are assets as long as they can provide many advantages to companies. Thus, several studies agree that political connections provide preferential access to debt, tax exemptions, and an opportunity to obtain a large market share. However, in evaluating the overall effect of political connections on firm performance, it is difficult to mediate between the benefits and costs of these connections, so the ultimate impact is not as certain. The study aimed to investigate the impact of political connections on the performance of South Korean companies. However, the effects of political connections can be a double-edged sword if they are created by distorting incentives and increasing the degree of corruption by misallocating investments [9]. As mentioned previously, politically friendly entities can benefit from easier access to debt financing or lower taxes and greater market dominance [6]. Previous research on the effects of political linkages is carried out using data from many countries, but because limited data are available in Korea, this work is different from past studies.

This study made several contributions. First, many prior studies only treat relationships between political and economic actors as having positive, negative, or no effects on the firm value in emerging and transitioning economies, and they do not investigate the effects of changes to the political and economic environments as time passes on the overall firm value from a contingency perspective. Hence, this study's findings contributed to the related literature by arguing that political capital is not immovable, instead, a firm can benefit positive benefits from reciprocal social network ties for a certain period. Second, this study found that political network ties remained significant determinants of the firm value even after South Korea achieved political and economic liberalization. Whether political connections gradually diminish in value or still play an actively significant role after political and economic liberalization is a heated topic of debate in the field of political economy. The empirical results of this study strongly support the notion that ties between CEOs, chairmen, or large shareholders and politicians, top government officials, or senior civil servants generate benefits. This result reflects the fact that, in a market economy, the government still controls resources after liberalization as the director of the market, the regulator of industry policies, and a patron of specific firms. Third, this study investigated the contingent value of political connections for firms in South Korea, a representative 
emerging economy. As Walder [31,32] mentions consequences of political capital dynamics vary widely across countries depending on the institutional environment.

Lastly, our findings particularly built upon the work of Chung, Byun, and Young [83]. They examine whether changes in the political environment can significantly affect firms' net values over time in emerging and transitioning economies. Our study was also related to that of Wang et al. [84]. They investigate the relationship between the political connections of firms' chairmen of the board and the amount of investment in energy conservation and emissions reduction. Their results show that politically connected board chairmen positively affect green investment. In addition, the degree of marketization negatively moderates the relationship between political connections and green investment, which supports an institutional logic perspective. Our study differed from that of Chung, Byun, and Young [83] and other studies [84-89] in that we specifically utilized changes in the value of political connections during times of political turnover and examined the effect of political connections between businesses and the government on firm value from 1998 to 2018, the most extensive sample period used to study this topic in South Korea.

Overall, the findings of this study provide implications regarding political connections and corporate relations. Government regulatory agencies are encouraged to continuously investigate firms' potential political linkages and set rules and regulations to proactively prevent such connections. Doing so will help to promote a sustainable fair market environment in the long run. However, this study had the limitation that, based on the definition of political support, the estimates were based on variation across the sample firms rather than variation over time. Executives' characteristics differ across firms but do not change much over time because their tenure lasts for some time. Future studies may resolve this issue with panel data.

Author Contributions: C.Y.C. designed the research. S.-I.S.H. performed the research and analyzed the data. S.-I.S.H. wrote the paper. D.C. and J.Y. revised the paper. All authors read and approved the final manuscript.

Funding: This work was supported by the research program of Kookmin University in Korea.

Conflicts of Interest: The authors declare no conflicts of interest.

\section{References}

1. Goldman, E.; Rocholl, J.; So, J. Do politically connected boards affect firm value? Rev. Financ. Stud. 2009, 22, 2331-2360. [CrossRef]

2. Imai, M. Mixing family business with politics in Thailand. Asian Econ. J. 2006, 20, 241-256. [CrossRef]

3. Khwaja, A.I.; Mian, A. Do lenders favor politically connected firms? Rent provision in an emerging financial market. Q. J. Econ. 2005, 120, 1371-1411. [CrossRef]

4. Ang, J.; Boyer, C. Finance and politics: The wealth effects of special interest group influence during the nationalization and privatization of Conrail. Camb. J. Econ. 2006, 31, 193-215. [CrossRef]

5. Fisman, R. Estimating the value of political connections. Am. Econ. Rev. 2001, 91, 1095-1102. [CrossRef]

6. Faccio, M. Politically connected firms. Am. Econ Rev. 2006, 96, 369-386. [CrossRef]

7. Claessens, S.; Feijen, E.; Laeven, L. Political connections and preferential access to finance: The role of campaign contributions. J. Financial Econ. 2008, 88, 554-580. [CrossRef]

8. Shleifer, A.; Vishny, R.W. Politicians and firms. Q. J. Econ 1994, 109, 995-1025.

9. Shleifer, A.; Vishny, R.W. The Grabbing Hand: Government Pathologies and Their Cures; Harvard University Press: Cambridge, MA, UK, 2002.

10. Hellman, J.S.; Jones, G.; Kaufmann, D. Seize the state, seize the day: State capture and influence in transition economies. J. Comp. Econ. 2003, 31, 751-773. [CrossRef]

11. Bertrand, M.; Kramarz, F.; Schoar, A.; Thesmar, D. Politicians, Firms and the Political Business Cycle: Evidence from France; University of Chicago: Chicago, IL, USA, 2006; Unpublished Working Paper.

12. Fan, J.P.; Wong, T.J.; Zhang, T. Politically connected CEOs, corporate governance, and post-IPO performance of China's newly partially privatized firms. J. Financ. Econ. 2007, 84, 330-357. [CrossRef]

13. Boubakri, N.; Cosset, J.; Saffar, W. Political connections of newly privatized firms. J. Corp. Financ. 2008, 14, 654-673. [CrossRef] 
14. Shleifer, A.; Vishny, R.W. Corruption. Q. J. Econ. 1993, 108, 599-617. [CrossRef]

15. Agrawal, A.; Knoeber, C.R. Do some outside directors play a political role? J. Law Econ. 2001, 44, 179. [CrossRef]

16. Zhu, H.; Chung, C. The portfolio of political ties and market entries of business groups in emerging economies. McMaster University: Hamilton, ON, Canada, 2010; Unpublished working paper.

17. Burt, R.S. The contingent value of social capital. Adm. Sci. Q. 1997, 42, 339-365. [CrossRef]

18. Yeh, Y.; Shu, P.; Chiu, S. Political connections, corporate governance and preferential bank loans. Pac. Basin Financ. J. 2013, 21, 1079-1101. [CrossRef]

19. Hillman, A.J.; Zardkoohi, A.; Bierman, L. Corporate political strategies and firm performance: Indications of firm-specific benefits from personal service in the US government. Strat. Manag. J. 1999, 20, 67-81. [CrossRef]

20. Kroszner, R.S.; Stratmann, T. Corporate campaign contributions, repeat giving, and the rewards to legislator reputation. J. Law Econ. 2005, 48, 41-71. [CrossRef]

21. Leuz, C.; Oberholzer-Gee, F. Political relationships, global financing, and corporate transparency: Evidence from Indonesia. J. Financ. Econ. 2006, 81, 411-439. [CrossRef]

22. Peng, M.W.; Luo, Y. Managerial ties and firm performance in a transition economy: The nature of a micro-macro link. Acad. Manag. J. 2000, 43, 486-501.

23. Kroszner, R.S.; Stratmann, T. Interest-group competition and the organization of Congress: Theory and evidence from financial services' political action committees. Am. Econ. Rev. 1998, 88, 1163-1187.

24. Smith, A. The Logic of Polit. Surviv.; MIT Press: Cambridge, MA, USA, 2005.

25. Bellettini, G.; Berti Ceroni, C.; Prarolo, G. Political Persistence, Connections and Economic Growth; Mimeo: New York, NY, USA, 2009; CESifo Working Paper.

26. Goldman, E.; Rocholl, J.; So, J. Political Connections and the Allocation of Procurement Contracts. 2008. Unpublished paper.

27. Choi, J.P.; Thum, M. The economics of politically-connected firms. Int. Tax Pub. Financ. 2009, 16, 605-620. [CrossRef]

28. Siegel, J. Contingent political capital and international alliances: Evidence from South Korea. Adm. Sci. Q. 2007, 52, 621-666. [CrossRef]

29. Parish, W.L.; Michelson, E. Politics and markets: Dual transformations. Am. J. Sociol. 1996, 101, $1042-1059$. [CrossRef]

30. Walder, A.G. Markets and inequality in transitional economies: Toward testable theories. Am. J. Sociol. 1996, 101, 1060-1073. [CrossRef]

31. Walder, A.G. Elite opportunity in transitional economies. Am. Sociol. Rev. 2003, 68, 899-916. [CrossRef]

32. Bunkanwanicha, P.; Wiwattanakantang, Y. Big business owners in politics. Rev. Financ. Stud. 2009, 22, 2133-2168. [CrossRef]

33. Boisot, M.; Child, J. From fiefs to clans and network capitalism: Explaining China's emerging economic order. Adm. Sci. Q. 1996, 41, 600-628. [CrossRef]

34. Boyd, B.K.; Haynes, K.T.; Hitt, M.A.; Bergh, D.D.; Ketchen, D., Jr. J. Contingency hypotheses in strategic management research. J. Manag. 2012, 38, 278-313. [CrossRef]

35. Ginsberg, A.; Venkatraman, N. Contingency perspectives of organizational strategy: A critical review of the empirical research. Acad. Manag. Rev. 1985, 10, 421-434. [CrossRef]

36. Woodward, J. Industrial Organization: Theory and Practice; Oxford University Press: London, UK, 1965.

37. Donaldson, I. The Contingency Theory of Organizations; Sage: London, UK, 2001.

38. Morton, N.A.; Hu, Q. Implications of the fit between organizational structure and ERP: A structural contingency theory perspective. Int. J. Inf. Manag. 2008, 28, 391-402. [CrossRef]

39. Wade, R. Governing the Market: Economic Theory and the Role of Government in East Asian Industrialization; University Press: Princeton, NJ, USA, 1990.

40. Fligstein, N.; Mara-Drita, I. How to make a market: Reflections on the attempt to create a single market in the European Union. Am. J. Sociol. 1996, 102, 1-33. [CrossRef]

41. Greif, A. Institutions and the Path to the Modern Economy: Lessons from Medieval Trade; Cambridge University Press: Cambridge, UK, 2006.

42. Pastor, L.; Veronesi, P. Uncertainty about government policy and stock prices. J. Financ. 2012, 67, 1219-1264. [CrossRef] 
43. Johnson, S.; Mitton, T. Cronyism and capital controls: Evidence from Malaysia. J. Financ. Econ. 2003, 67, 351-382. [CrossRef]

44. Holburn, G.L.; Vanden Bergh, R.G. Consumer capture of regulatory institutions: The creation of public utility consumer advocates in the United States. Public Choice 2006, 126, 45-73. [CrossRef]

45. Do, Q.; Lee, Y.; Nguyen, B.D.; Nguyen, K. Out of Mind: The Value of Political Connections in Social Networks; Singapore Management University: Singapore, 2012; Unpublished working paper.

46. Li, H.; Meng, L.; Wang, Q.; Zhou, L. Political connections, financing and firm performance: Evidence from Chinese private firms. J. Dev. Econ. 2008, 87, 283-299. [CrossRef]

47. Adhikari, A.; Derashid, C.; Zhang, H. Public policy, political connections, and effective tax rates: Longitudinal evidence from Malaysia. J. Acc. Public Policy 2006, 25, 574-595. [CrossRef]

48. Hu, F.; Leung, S. Appointment of Political Top Executives and Subsequent Performance and Corporate Governance: Evidence from China's Listed SOEs. Available online: http://ssrn.com/abstract=1361617.2009 (accessed on 23 September 2018).

49. Chang, E.C.; Wong, S.M. Corporate Governance, Political Interference, and Corporate Performance of China's Listed Companies. 2002. Working paper.

50. Chen, D.; Fan, J.P.; Wong, T. Politically-connected CEOs, Corporate Governance and post-IPO Performance of China's Partially Privatized Firms; Chinese University of Hong Kong: Hong Kong, China, 2004; Working paper.

51. Liu, Q.; Luo, W.; Xu, N. Political motivation, over-investment and firm performance; Singapore Management University, 2013, Unpublished working paper.

52. Hellman, J.; Schankerman, M. Intervention, corruption and capture: The nexus between enterprises and the state. Econ. Transit. 2000, 8, 545-576. [CrossRef]

53. Shen, C.; Wang, Y.; Lin, C. Do strong corporate governance firms still require political connection? and vice versa? Int. Rev. Econ Financ. 2012, 39, 107-120. [CrossRef]

54. Wong, S.H. Political connections and firm performance: The case of Hong Kong. J. East Asian Stud. 2010, 10, 275-313. [CrossRef]

55. Ang, J.S.; Ding, D.K.; Thong, T.Y. Political Connection and Firm Value. Massey. Asian Dev. Rev. 2011, 31, 131-166.

56. Niessen, A.; Ruenzi, S. Political connectedness and firm performance: Evidence from Germany. Ger. Econ. Rev. 2010, 11, 441-464. [CrossRef]

57. Haveman, H.A.; Jia, N.; Shi, J.; Wang, Y. China's economic transition and the value of firms' political connections: A longitudinal study of publicly listed firms. University of Illinois: Champaign, IL, USA, 2013; Unpublished working paper.

58. Qin, B. Political connection and government patronage: Evidence from Chinese manufacturing firms, Institute for International Economic Studies; IIES Stockholm University: Stockholm, Sweden, 2011; Unpublished working paper.

59. Nee, V.; Opper, S. Political connections in a market economy. Soc. Forces 2010, 88, 2105-2132. [CrossRef]

60. Sheng, S.; Zhou, K.Z.; Li, J.J. The effects of business and political ties on firm performance: Evidence from China. J. Mark. 2011, 75, 1-15. [CrossRef]

61. Solinger, D.J. Urban entrepreneurs and the state: The merger of state and society. In State and Society in China; Rosenbaum, A.L., Ed.; Westview: Boulder, CO, USA, 1992; pp. 121-142.

62. Sapienza, P. The effects of banking mergers on loan contracts. J. Financ. 2002, 57, 329-367. [CrossRef]

63. Ferguson, T.; Voth, H. Betting on Hitler-the value of political connections in Nazi Germany. Q. J. Econ. 2008, 123, 101-137. [CrossRef]

64. Imai, M.; Shelton, C.A. Elections and Political Risk: New Evidence from Political Prediction Markets in Taiwan. 2010. Unpublished paper.

65. Bandeira-de-Mello, R.; Marcon, R.; Burstein Goldszmidt, R.G.; Zambaldi, F. Firm performance effects of nurturing political connections through campaign contributions. Afr. J. Bus. Manag. 2012, 6, 3327-3332. [CrossRef]

66. Hung, M.; Wong, T.; Zhang, T. Political considerations in the decision of Chinese SOEs to list in Hong Kong. J. Acc. Econ. 2012, 53, 435-449. [CrossRef]

67. Jayachandran, S. The Jeffords effect. J. Law Econ. 2006, 49, 397-425. [CrossRef]

68. Rajwani, T.; Liedong, T.A. Political activity and firm performance within nonmarket research: A review and international comparative assessment. J. World Bus. 2014, 50, 273-283. 
69. Kang, Y.S.; Kook, C.P. Independence and corporate value of private directors. Financ. Res. 2012, 25, 451-498.

70. Kim, J.K.; Shin, J.Y. The impact of the independence of the board on the value of entrepreneurship: Focusing on the social connection of outside directors. J. Korea Secur. Assoc. 2016, 45, 713-739.

71. Kim, C.S. Corporate social responsibility and corporate value. J. Korea Secur. Assoc. 2009, 38, 507-545. [CrossRef]

72. Demsetz, H.; Lehn, K. The structure of corporate ownership: Causes and consequences. J. Polit. Econ. 1985, 93, 1155-1177. [CrossRef]

73. Modigliani, F.; Miller, M.H. Corporate income taxes and the cost of capital: A correction. Am. Econ. Rev. 1963, 53, 433-443.

74. Myers, S.C. Determinants of corporate borrowing. J. Financ. Econ. 1977, 5, 147-175. [CrossRef]

75. Jensen, M.C. Agency costs of free cash flow, corporate finance, and takeovers. Am. Econ. Rev. 1986, 76, 323-329.

76. Stulz, R. Managerial discretion and optimal financing policies. J. Financ. Econ. 1990, 26, 3-27. [CrossRef]

77. Shleifer, A.; Vishny, R.W. Management entrenchment: The case of manager-specific investments. J. Financ. Econ. 1989, 25, 123-139. [CrossRef]

78. Yermack, D. Higher market valuation of companies with a small board of directors. J. Financ. Econ. 1996, 40, 185-211. [CrossRef]

79. Neter, J.; Wasserman, W.; Kutner, M.H.; Li, W. Applied Linear Statistical Models. Irwin Publishing: Burr Ridge, IL, USA, 1996.

80. Criscuolo, C.; Martin, R.; Overman, H.G.; Van Reenen, J. Some causal effects of an industrial policy. Am. Econ. Rev. 2019, 109, 48-85. [CrossRef]

81. Chung, C.Y.; Byun, J.H.; Young, J. Corporate political ties and firm value: Comparative analysis in the Korean market. Sustainability 2019, 11, 327. [CrossRef]

82. Wang, K.; Zhang, H.M.; Tsai, S.B.; Wu, L.D.; Xue, K.K.; Fan, H.J.; Chen, Q. Does a board chairman's political connection affect green investment?-From a sustainable perspective. Sustainability 2018, 10, 582. [CrossRef]

83. Chung, C.Y.; Liu, C.; Wang, K.; Zykaj, B.B. Institutional monitoring: Evidence from the F-score. J. Bus. Financ. Acc. 2015, 42, 885-914. [CrossRef]

84. Liu, C.; Chung, C.Y.; Sul, H.K.; Wang, K. Does hometown advantage matter? The case of institutional blockholder monitoring on earnings management in Korea. J. Int. Bus. Stud. 2018, 49, 196-221. [CrossRef]

85. Choi, P.M.S.; Chung, C.Y.; Hwang, J.H.; Liu, C. Heads I win, tails you lose: Institutional monitoring of executive pay rigidity. J. Financ. Res. 2019, 42, 789-816. [CrossRef]

86. Choi, P.M.S.; Chung, C.Y.; Liu, C. Self-attribution of overconfident CEOs and asymmetric investment-cash flow sensitivity. North Am. J. Econ. Financ. 2018, 46, 1-14.

87. Chung, C.Y.; Hur, S.K.; Liu, C. Institutional investors and cost stickiness: Theory and evidence. North Am. J. Econ. Financ. 2019, 47, 336-350. [CrossRef]

88. Chung, C.Y.; Jung, S.; Young, J. Do CSR activities increase firm value? Evidence from the Korean market. Sustainability 2018, 10, 3164. [CrossRef]

89. Cho, S.J.; Chung, C.Y.; Young, J. Study on the Relationship between CSR and Financial Performance. Sustainability 2019, 11, 343. [CrossRef]

(C) 2020 by the authors. Licensee MDPI, Basel, Switzerland. This article is an open access article distributed under the terms and conditions of the Creative Commons Attribution (CC BY) license (http://creativecommons.org/licenses/by/4.0/). 